\title{
Protective immunity against Trichinella spiralis infection induced by TsNd vaccine in mice
}

\author{
Pei Liu', Jing Cui ${ }^{1 *}$, Ruo Dan Liu', Min Wang², Peng Jiang ${ }^{1}$, Li Na Liu', Shao Rong Long ${ }^{1}$, Ling Ge Li', \\ Shuai Bing Zhang ${ }^{1}$, Xin Zhuo Zhang ${ }^{1}$ and Zhong Quan Wang ${ }^{1 *}$
}

\begin{abstract}
Background: We have previously reported that Trichinella spiralis Nudix hydrolase (TsNd) bound to intestinal epithelial cells (IECs), and vaccination of mice with recombinant TsNd protein ( $r T s \mathrm{Nd}$ ) produced a partial protective immunity. The aim of this study was to investigate the immune protection induced by TsNd DNA vaccine.

Methods: The full-length cDNA sequence of TsNd gene was cloned into pcDNA3.1 and used to immunize BALB/c mice by intramuscular injection. Transcription and expression of TsNd were detected by RT-PCR and IFT. The levels of specific $\lg A, \operatorname{lgG}, \lg G 1$ and $\lg G 2 a$, and cytokines were assayed by ELISA at weeks 0,6 and 8 post-immunization. The immune protection of TsNd DNA vaccine against challenge infection was investigated.

Results: Immunization of mice with TsNd DNA elicited a systemic Th1/Th2 immune response and a local mucosal IgA response. The in vitro transcription and expression of TsNd gene was observed at all developmental stages of $T$. spiralis (ML, ILL, AW and NBL). Anti-rTsNd IgG levels were increased after immunization and levels of IgG1 were obviously higher than that of IgG2a. Intestinal specific IgA levels of immunized mice were significantly higher than those of vector and PBS control mice. Cytokine profiling also showed a significant increase in Th1 (IFN- $\gamma$, IL-2) and Th2 $(I L-4,10)$ responses in splenocytes of immunized mice on stimulation with $r T s N d$. Vaccination of mice with pcDNA3.1-TsNd displayed a 40.44\% reduction in adult worms and a 53.9\% reduction in larval burden.
\end{abstract}

Conclusions: TsNd DNA induced a mixed Th1/Th2 immune response and partial protection against $T$. spiralis infection in mice.

Keywords: Trichinella spiralis, Nudix hydrolase (Nd), DNA vaccine, Th1/Th2

\section{Background}

Trichinella spiralis is a parasitic nematode that infects humans and other mammals [1]. Trichinellosis, caused by the consumption of raw or undercooked meat contaminated with Trichinella infective muscle larvae, remains an important food-borne disease with a nearly worldwide distribution [2]. In the past several decades, many outbreaks of human trichinellosis have been reported in different areas of the world [3]. From 2004 to 2009, 15 outbreaks of human trichinellosis, with 1387 cases and 4 deaths, were reported in China [4]. The occurrence of trichinellosis in humans is strictly related to cultural food practices, pork is the most important

\footnotetext{
*Correspondence: cuij@zzu.edu.cn; wangzq@zzu.edu.cn

'Department of Parasitology, Medical College, Zhengzhou University, 40 Daxue Road, Zhengzhou 450052, P. R. China

Full list of author information is available at the end of the article
}

source of human Trichinella infection in China [5]. Trichinellosis is not only a public health hazard but also an economic problem in porcine animal production and food safety [6]. Due to the predominantly zoonotic importance of Trichinella infection, the development of vaccines capable of preventing swine from becoming infected is a promising measure for control of trichinellosis [7-9].

T. spiralis muscle larvae (ML) are released from the muscle tissue in the stomach by the digestive enzymes, and activated into the intestine infective larvae (IIL) by exposure to intestinal contents or bile. Then the IIL invade host's intestinal epithelium where the larvae develop into adult worms (AW) that mate and reproduce the next generation of larvae [10]. Therefore, the intestinal mucosa is the first natural barrier in protecting the host against Trichinella infection. In our previous study, T. spiralis Nudix hydrolase (TsNd) protein binding to 
normal mouse intestinal epithelial cells (IECs) were identified by screening a T7 phage display cDNA library from $T$. spiralis IIL [11]. TsNd gene (GenBank accession No. EU263318.1) was also an up-regulated gene in IIL compared to ML, which was identified by using suppression subtractive hybridization (SSH) and confirmed by realtime PCR [12]. The TsNd gene was about $1248 \mathrm{bp}$. The predicted open reading frame (ORF) of TsNd encodes 415 amino acids with a molecular weight of $46 \mathrm{kDa}$ and an isoelectric point (pI) of 8.85. Conserved domain analysis of $\mathrm{TsNd}$ revealed there was one Nudix motif located at 226-244 aa. The vaccination of mice with recombinant TsNd protein (rTsNd) produced a partial protective immunity against $T$. spiralis infection [13].

In recent years, many promising results and significant protection have been reported for viral, bacterial, and parasitic infections using the DNA heterologous primeboost vaccination [14-16]. In this study, to observe the immune protection induced by TsNd DNA vaccine, the full-length cDNA sequence of $\mathrm{TsNd}$ gene was cloned into the eukaryotic expression vector pcDNA3.1 and used to immunize $\mathrm{BALB} / \mathrm{c}$ mice by intramuscular injection. In addition, the humoral and cellular immune responses elicited by the DNA vaccine were investigated.

\section{Methods}

\section{Ethics statement}

This study was carried out in strict accordance with the National Guidelines for Experimental Animal Welfare (MOST of People's Republic of China, 2006). All animal procedures reported herein were reviewed and approved by the Zhengzhou University Animal Care and Use Committee (Permission No. SYXK 2012-0009).

\section{Parasite and experimental animals}

The isolate (ISS534) of T. spiralis used in this study was obtained from domestic pigs in Nanyang, Henan Province, China. The Trichinella isolate was maintained by serial passage in Kunming mice every 6-8 months. Specific pathogen-free (SPF) female BALB/c mice aged 6-8 weeks were obtained from the Laboratory Animal Center of the Experimental Animal Center of Henan Province.

\section{Collection of worms}

$T$. spiralis $\mathrm{ML}$ from infected mice at 35 days postinfection (dpi) were recovered by digestion of carcasses with $0.33 \%$ pepsin (1:31000; Sigma) and $1 \% \mathrm{HCl}$ [17]. The IIL was collected from the mouse small intestines at 6 hours post-infection (hpi). Adult worms (AW) were isolated from the small intestines of infected mice at 7 dpi [18]. The newborn larvae (NBL) were collected from female adult worms cultured in RPMI-1640 medium containing $10 \%$ fetal bovine serum (FBS; Gibco) in 5\% $\mathrm{CO}_{2}$ at $37^{\circ} \mathrm{C}$ for $24 \mathrm{~h} \mathrm{[19].}$

\section{Plasmid construction and sequence analysis of recombinant expression plasmids}

The full-length TsNd gene (GenBank accession No. EU263318.1) was obtained by PCR amplification using the following primers: 5-AGGATCCGCCACCATGT TTTACTTGGTAA CG-3 (forward), 5-ACTCGAGTTA CCAAGTGTGTTGCAAAGCAATC-3 (reverse). The BamHI and Xhol sites are bold and italicized. DNA encoding the full-length TsNd was cloned into the eukaryotic expression vector pcDNA3.1 as DNA vaccine (pcDNA3.1TsNd). An artificial Kozak sequence (GCCACC) was included in sense primers to permit efficient initiation of translation [20]. Amplicons were ligated into the expression vector pcDNA3.1 (Invitrogen, USA) and transformed into $E$. coli DH5a (Invitrogen). Clones containing inserts of the expected size were selected by restriction digestion and subjected to DNA sequencing using T7 and BGH primers by Invitrogen (Invitrogen Co. Ltd, Shanghai, China). DNA and predicted amino acid sequences were analyzed using Lasergene 7.1 software (DNASTAR Inc., Madison, Wisconsin, USA). The plasmid DNA was extracted by alkaline cleavage method [16].

\section{Expression and purification of recombinant TsNd protein (rTsNd)}

The full-length TsNd gene was cloned into the expression vector pMAL-c2X (New England Biolabs, USA). The rTsNd protein was expressed in E. coli under $0.5 \mathrm{mM}$ IPTG induction as described previously [13]. The rTsNd protein was purified by Amylose Pre-packed Column (NEB Ltd, China). The mouse anti-rTsNd serum was collected from the mice immunized with rTsNd obtained at one week after the last immunization as described previously [21].

\section{RT-PCR and immunofluorescent test (IFT)}

The baby hamster kidney cells (BHK-21) were plated in 6-well tissue culture plates (Nunc) at $2 \times 10^{6}$ cells per well in RPMI-1640 containing 5\% FBS [22]. The recombinant pcDNA3.1-TsNd and pcDNA3.1 $\left(1 \times 10^{8} / \mathrm{mL}\right)$ were transfected into the BHK-21 cells with Lipofectamine 2000 (Invitrogen, USA) following the manufacturer's instructions. For RT-PCR assays, total RNA was extracted from the transfected BHK-21 cells using TRIzol reagent (Invitrogen, USA) following the manufacturer's instructions. The cDNA samples were obtained using a cDNA First Strand Synthesis Kit (Bioer Technology, China). Transcription of the TsNd gene in the transfected BHK-21 cells was analyzed by RT-PCR using specific primers listed above. For IFT, BHK-21 cells expressing TsNd proteins were cultured as monolayers and washed with PBS and fixed with $4 \%$ acetone at room temperature for $20 \mathrm{~min}$. Then, cells were washed with PBS and permeabilized with $1 \%$ TritonX- 100 at $4{ }^{\circ} \mathrm{C}$ for 
$10 \mathrm{~min}$, after which the cells were further incubated with mouse anti-rTsNd serum (1:10 dilution) at $37^{\circ} \mathrm{C}$ for $1 \mathrm{~h}$. After washing three times in PBS, the cells were incubated with a 1:50 dilution of FITC-labeled goat anti-mouse IgG (Santa Cruz, USA) in PBS at room temperature for $1 \mathrm{~h}$, after washing three times in PBS, and examined under a fluorescent microscope (Olympus, Japan).

\section{Immunization schedule and sample collection}

$\mathrm{BALB} / \mathrm{c}$ mice were randomly divided into three groups of 40 animals each. Pre-immune sera were collected by tail bleeding 2 days prior to the first vaccination. The vaccine group of mice was intramuscularly injected with TsNd-pcDNA3.1. The control group was injected with pcDNA3.1 or PBS. The vaccination was administered four times at 2-week intervals. For intramuscular vaccination, mice were injected with $50 \mu \mathrm{g}$ of pure plasmid DNA (in $50 \mu \mathrm{l}$ of PBS) in the left and right quadriceps of legs [15]. At weeks 0,6 and 8 post-immunization, ten mice from each group were euthanized; the serum, intestinal lavage fluid, and spleen were collected to evaluate the humoral and cellular immune responses.

\section{Evaluation of humoral immune responses by ELISA}

The levels of the specific total IgG, IgG1 and IgG2a antibodies to TsNd in serum samples of immunized mice were determined by ELISA with rTsNd as described previously $[23,24]$. Briefly, microtiter plates (Nunc) were coated with $\mathrm{rTsNd}(2.5 \mu \mathrm{g} / \mathrm{ml})$ in coating buffer overnight at $4^{\circ} \mathrm{C}$, and blocked with $200 \mu \mathrm{l}$ of PBS-0.1\% Tween 20 (PBST) containing $5 \%$ skimmed milk. Then, $100 \mu \mathrm{l}$ of serum samples with 1:100 dilution in PBS were added to each well and incubated at $37^{\circ} \mathrm{C}$ for $1 \mathrm{~h}$. HRP-conjugated antimouse IgG, IgG1 or IgG2a (1:5000; Southern Biotechnology, USA) were added and incubated at $37^{\circ} \mathrm{C}$ for $1 \mathrm{~h}$. The reactions were detected by addition of the substrate ophenylenediamine dihydrochloride (OPD; Sigma) plus $\mathrm{H}_{2} \mathrm{O}_{2}$ and stopped with $50 \mu \mathrm{l} /$ well of $2 \mathrm{M} \mathrm{H}_{2} \mathrm{SO}_{4}$. Absorbance at $490 \mathrm{~nm}$ was measured with a microplate reader (TECAN, Austria). All samples were run in duplicate.

\section{Recognition of the native $\mathrm{TsNd}$ in $T$. spiralis different stages by IFT}

The recognition of the native TsNd in T. spiralis different developmental stages (ML, IIL, AW, and NBL) was observed by IFT as described previously $[25,26]$. The intact whole worms were fixed in aceton and further incubated with anti-rTsNd serum from mice immunized by TsNd DNA (1:10 dilution) at $37^{\circ} \mathrm{C}$ for $1 \mathrm{~h}$. After being washed three times in PBS, the whole parasites were incubated with a 1:50 dilution of FITC-labeled goat anti-mouse IgG (Santa Cruz, USA), washed five times in PBS, and examined under a fluorescent microscope (Olympus, Japan).

\section{Measurement of total $\lg A$ and specific $\lg A$ in intestinal washings}

To determine the specific IgA, the interior of the small intestine from immunized mice was washed twice with a total of $1 \mathrm{ml}$ of cold PBS. After centrifugation at $800 \mathrm{~g}$ for $10 \mathrm{~min}$, the supernatants of the intestinal washes were harvested. The specific anti-TsNd IgA was measured by standard ELISA using an rTsNd-coated plate. Total IgA was quantified by a sandwich ELISA using rabbit anti-mouse IgA antibody (Abcam, UK) as the capture antibody and HRP-conjugated goat anti-mouse IgA antibodies as the detection antibody. To compensate for variations in the efficiency of the recovery of secretory IgA antibodies among animals, the antigen-specific IgA in each sample was normalized to the total IgA present in the lavage.

\section{Cytokine assays}

To examine the specific cellular immune responses, spleen cells were aseptically removed from immunized and control mice at weeks 0,6 and 8 post-immunization, respectively [27]. The density of spleen cells obtained from each mouse was adjusted to $2 \times 10^{6}$ cells $/ \mathrm{ml}$ in complete RPMI-1640 containing 10\% fetal bovine serum (FBS), $100 \mathrm{U} / \mathrm{ml}$ penicillin and $100 \mathrm{U} / \mathrm{ml}$ streptomycin. Spleen cells in 96-well plates were stimulated with the rTsNd $\left(2 \times 10^{10} \mathrm{pfu} / \mathrm{ml}\right)$ at $37^{\circ} \mathrm{C}$ for $48 \mathrm{~h}$ in a humidified $5 \% \mathrm{CO}_{2}$ atmosphere. Supernatants were collected and cytokines (IL-2, IFN- $\gamma$, IL-4, and IL-10) were measured by ELISA [28]. Simultaneously, the cells were incubated with ConA as a positive control and RPMI 1640 medium alone as a negative control. Cytokine concentrations were determined by comparison with standard curves constructed with known amounts of the respective mouse recombinant cytokines. The Results were expressed in picograms per milliliter $(\mathrm{pg} / \mathrm{ml})$.

\section{Challenge infection}

One week after the final vaccination, the remaining 60 mice from the 3 groups (20 mice for each group) were orally challenged with $300 \mathrm{~T}$. spiralis ML. Ten mice from each group were euthanized 7 days after challenge and the numbers of intestinal adult worms were counted [23]. The muscle larvae were examined by artificial digestion from another 10 mice from each group 35 days after challenge [21]. The protective immunity was calculated as the worm reduction rate of recovered adults and larvae per gram (LPG) muscle from the immunized groups versus those from the control group [15,29].

\section{Statistical analysis}

Data were expressed as the mean \pm standard deviation. Intra-and intergroup statistical analyses were performed with one-way ANOVA (LSD test) using SPSS version 
17.0 software. $P<0.05$ was considered as statistically significant.

\section{Results}

Construction of recombinant pcDNA3.1-TsNd

The full-length cDNA encoding TsNd was cloned into pcDNA3.1, the recombinant plasmid pcDNA3.1-TsNd was digested with $\mathrm{BamHI} / \mathrm{XhoI}$ and the results revealed that the recombinant plasmid contained an insert of about $1248 \mathrm{bp}$ (Figure 1). Sequence analysis indicated that the amplified fragment of TsNd consisted of $1248 \mathrm{bp}$, and the predicted ORF encoded a protein of 415 amino acid residues with a molecular mass of $46 \mathrm{kDa}$ and $99.7 \%$ identity to the published sequence of TsNd in GenBank (EU263318.1).

The in vitro transcription and expression of TsNd gene The in vitro transcription of TsNd gene in the BHK-21 cells was analyzed by RT-PCR. PCR products were analyzed on a $1 \%$ agarose gel with ethidiumbromide staining. The amplified TsNd fragment was observed in pcDNA3.1-TsNd group, but the amplified fragment was not observed in pcDNA3.1 control group (Figure 2A). Expression of TsNd gene in BHK-21 cells was detected by IFT. The intense green fluorescent staining using anti-rTsNd serum was observed in BHK-21 cells transfected with pcDNA3.1-TsNd, but not detected in plasmid pcDNA3.1 control group (Figure 2B).

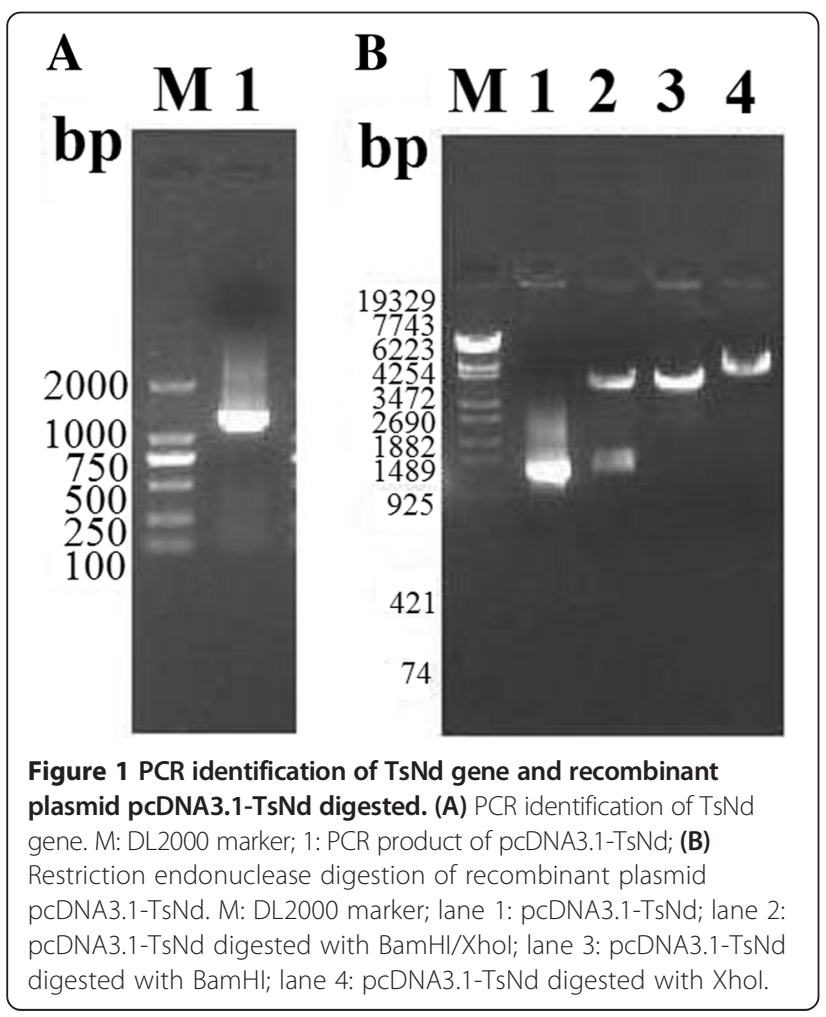

Humoral immune responses induced by immunization with pcDNA3.1-TsNd

The mouse sera collected at different time points after immunization were used to measure levels of specific anti-TsNd IgG and its subtype (IgG1 and IgG2a) antibodies. Anti-TsNd IgG levels in mice immunized with pcDNA3.1-TsNd were significantly increased following the second and third immunization. However, none of the mice vaccinated with pcDNA3.1 or PBS showed significantly detectable TsNd-specific IgG antibody responses (Figure 3A). In the immunized group with pcDNA3.1TsNd (Figure 3B), the levels of IgG1 on week 4 and 6 after the first immunization were more obviously higher than that of IgG2a $\left(\mathrm{t}_{4 \mathrm{w}}=24.756, \mathrm{t}_{6 \mathrm{w}}=30.163, P<0.01\right)$. However, it was notable that IgG2a was induced on week 4 and 6. This suggests that vaccination with pcDNA3.1TsNd elicited a Th1/Th2-mixed type of immune response with Th2 predominance.

\section{Recognition of the native TsNd at $T$. spiralis different stages by IFT}

The results of IFT with the whole parasites showed that the intense fluorescent staining using anti-rTsNd serum was found on the surface of all different developmental stages of T. spiralis (e.g., ML, IIL at $6 \mathrm{hpi}$, AW at $3 \mathrm{dpi}$, AW at $7 \mathrm{dpi}$ and NBL). Serum from mice vaccinated with empty plasmid pcDNA3.1 or PBS did not recognize the T. spiralis different stages (Figure 4).

\section{Mucosal immune response}

Intestinal total IgA levels were significantly increased in mice immunized with pcDNA3.1-TsNd compared with those immunized with vector alone or PBS $(P<0.05)$. Intestinal specific anti-TsNd IgA levels of mice immunized with pcDNA3.1-TsNd were obviously higher than those of immunized with vector alone or PBS $(P<0.05)$. And statistical difference was also observed in ratio of specific IgA/total IgA in immunized group compared with those vaccinated with empty plasmid pcDNA3.1 alone or PBS $(P<0.05)$ (Figure 5).

\section{Cytokine responses to the immunization with pcDNA3.} 1-TsNd

At week 6 after immunization, the spleen cells from mice immunized with pcDNA3.1-TsNd produced significantly higher levels of IFN- $\gamma$, IL-2, IL-4, and IL-10, compared with those before immunization $(P<0.01)$ (Figure 6). Moreover, the levels of four cytokines in immunized mice continued to increase at week 8 after immunization (one week after challenge). Compared with the empty plasmid pcDNA3.1 and PBS control groups, the levels of four cytokines in immunized mice were statistically obviously increased at week 6 and 8 after immunization $(P<0.01)$, suggesting that the vaccination of mice with 


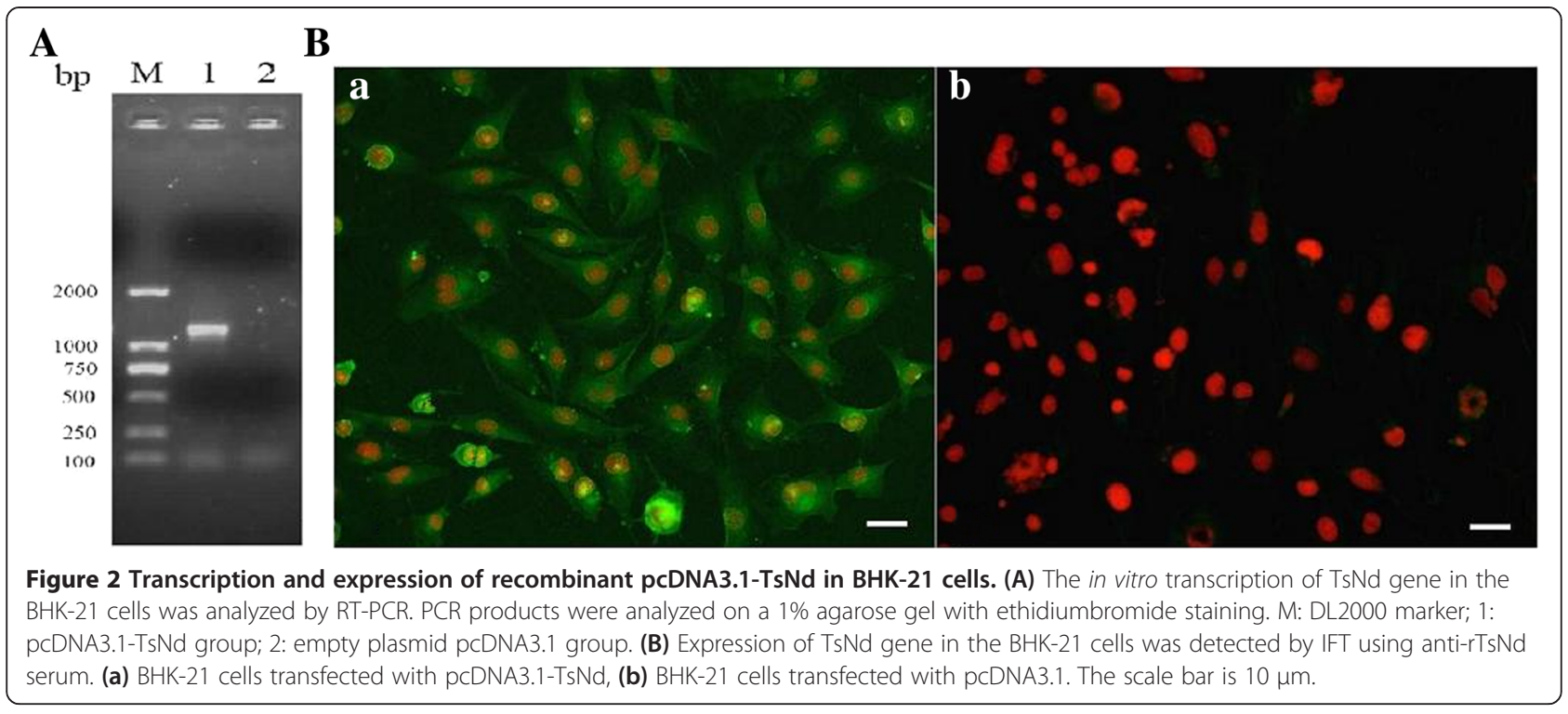

pcDNA3.1-TsNd induced the Th1/Th2-mixed type of immune response.

\section{Immune protection}

To evaluate the efficacy of the recombinant DNA vaccine strategy, the adult worm burden and the muscle larval burden were examined. After the challenge infection with $T$. spiralis muscle larvae, the mice immunized with pcDNA3.1-TsNd displayed a statistically significant $40.44 \%$ reduction in adult worm burden and a $53.9 \%$ reduction in muscle larvae (Figure 7 ), compared with PBS control group $\left(F_{\text {adults }}=43.265, F_{\text {larvae }}=14.598\right.$, $P<0.05)$. The results demonstrated that the immunization with DNA vaccine induced the partial immune protection against challenge infection with $T$. spiralis larvae.

\section{Discussion}

In some countries (such as Mexico, Argentine, Thailand, China, Vietnam and some Eastern European countries), pigs are frequently raised in backyards where pigs were often fed on raw swills [30,31], the prevalence of swine Trichinlla infection is higher in backyards and small farms of some countries. It is very difficult to change the farmers' habits of pig breeding with raw swills. Thus, vaccines are urgently needed to prevent swine from Trichinella infection. In our previous study, the rTsNd was expressed in an E. coli expression system and the vaccination of mice with rTsNd induced a partial protective immunity against $T$. spiralis infection [13]. However, the expressed proteins in prokaryotic plasmids may differ from the native active protein in terms of structure and function [32].
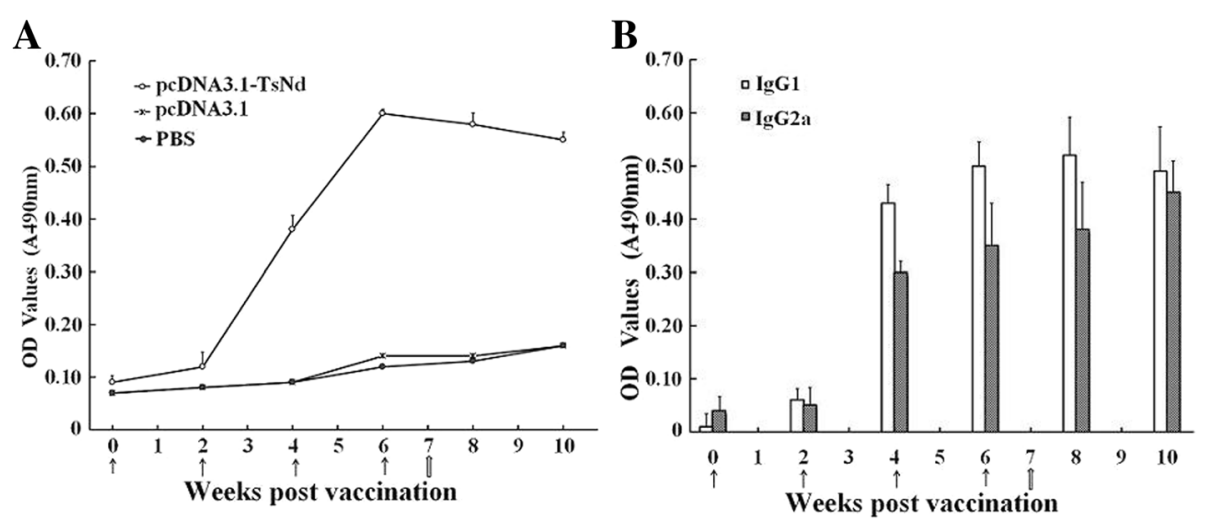

Figure 3 Mouse IgG (A) and IgG subclass (B) responses to the immunization with pcDNA3.1-TsNd as measured by ELISA with rTsNd. The OD values shown for each group are the mean \pm standard deviation (SD) of antibody levels $(n=10)$. The immunization time points are marked as solid arrows ( $\uparrow$ ), and the challenge time is marked as empty arrow $(\hat{\Uparrow})$. 


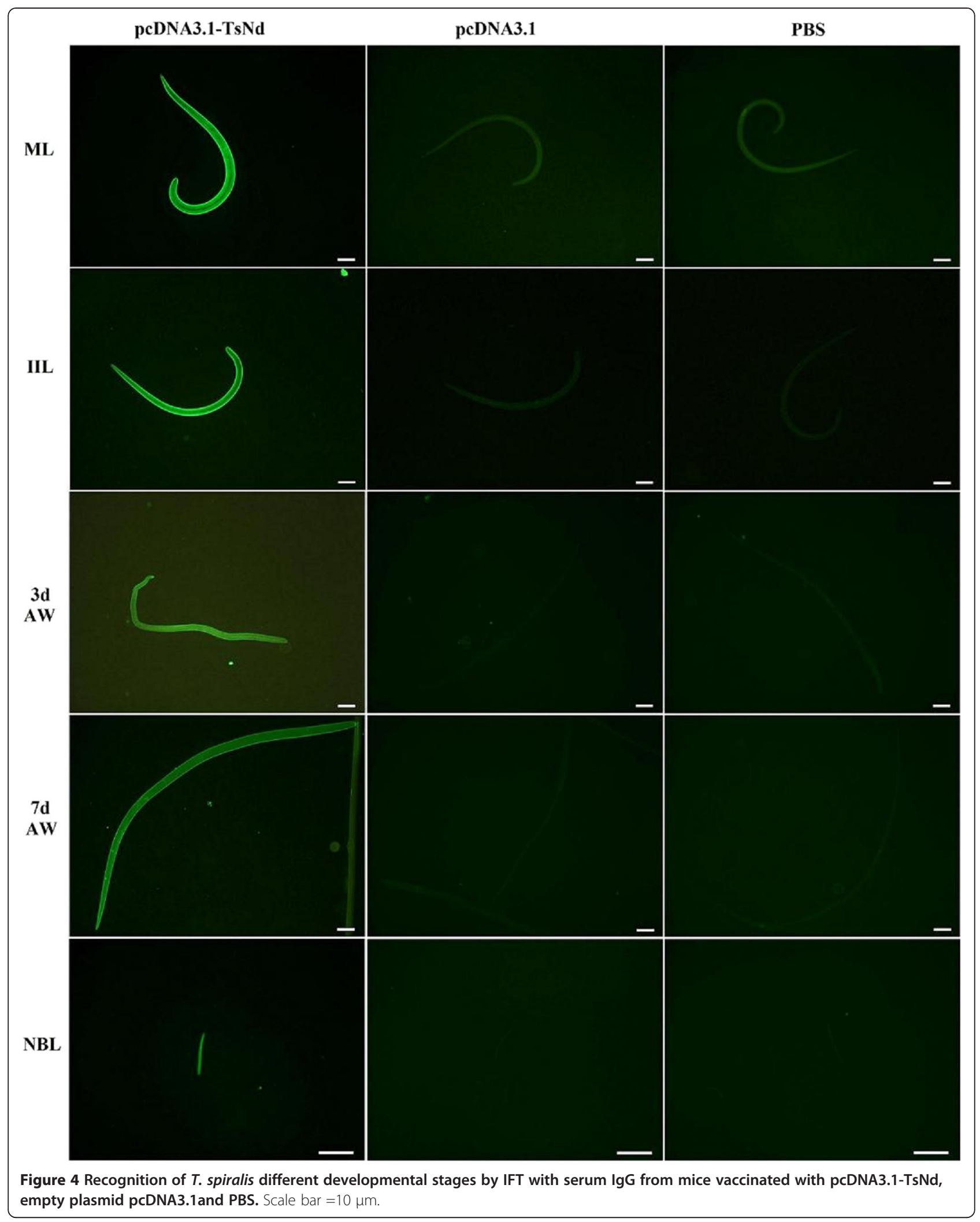



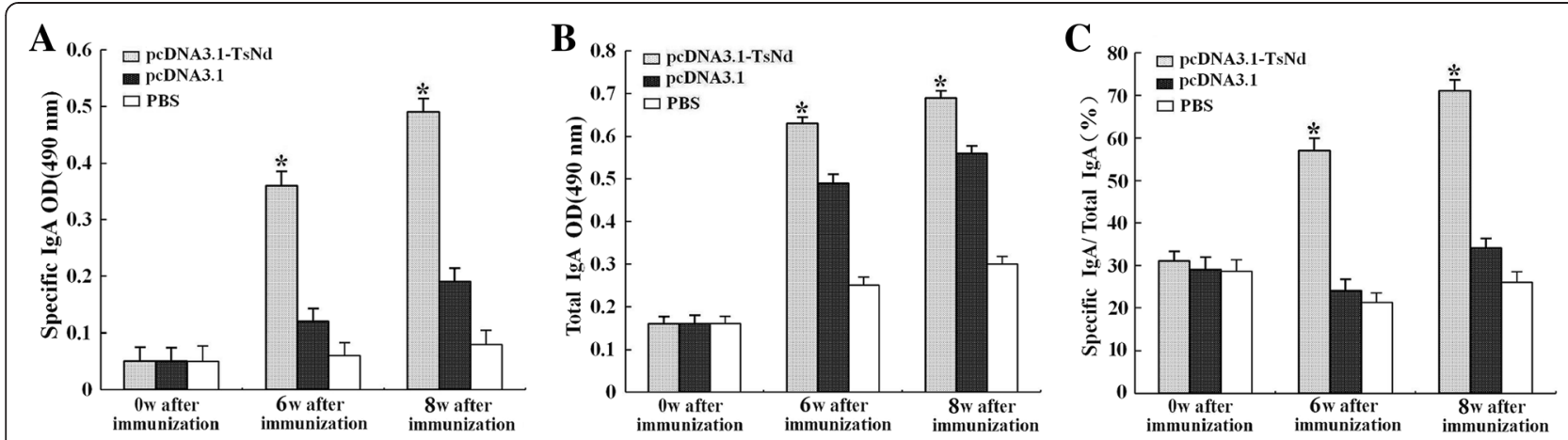

Figure 5 Anti-TsNd-specific $\lg A(A)$, total $\lg A(B)$ and specific $\lg A /$ total $\lg A(C)$ in intestinal washings of mice immunized with pcDNA3.1-TsNd, vector or PBS. Results are the mean \pm standard deviation (SD) for 10 mice per group. Asterisks (*) indicate statistically significant differences $(P<0.05)$ compared to the empty plasmid pcDNA3.1 or PBS control group.

DNA vaccination becomes more attractive because of its ability to induce a broad range of immune responses and long lasting immunity. However, DNA vaccines remain poorly immunogenic compared to protein vaccines [33]. An effective vaccine usually requires more than one immunization in the form of a prime-boost. In addition, the plasmid DNA is most commonly delivered by intramuscular inoculation or via the gene gun bombardment [7], but the later is practically inconvenient in terms of cost and simplicity. It was also reported that the intramuscular route was the best one among five delivery routes, including oral administration [34]. In the present study, to improve the efficacy of vaccination, the DNA encoding the protective antigen TsNd was cloned into the eukaryotic expression plasmid, and the recombinant TsNd DNA was used to immunize mice by intramuscular injection to induce the protective immunity against $T$. spiralis infection. The results showed that a TsNd DNA vaccine elicited a specific immune response and partial protection against $T$. spiralis challenge in
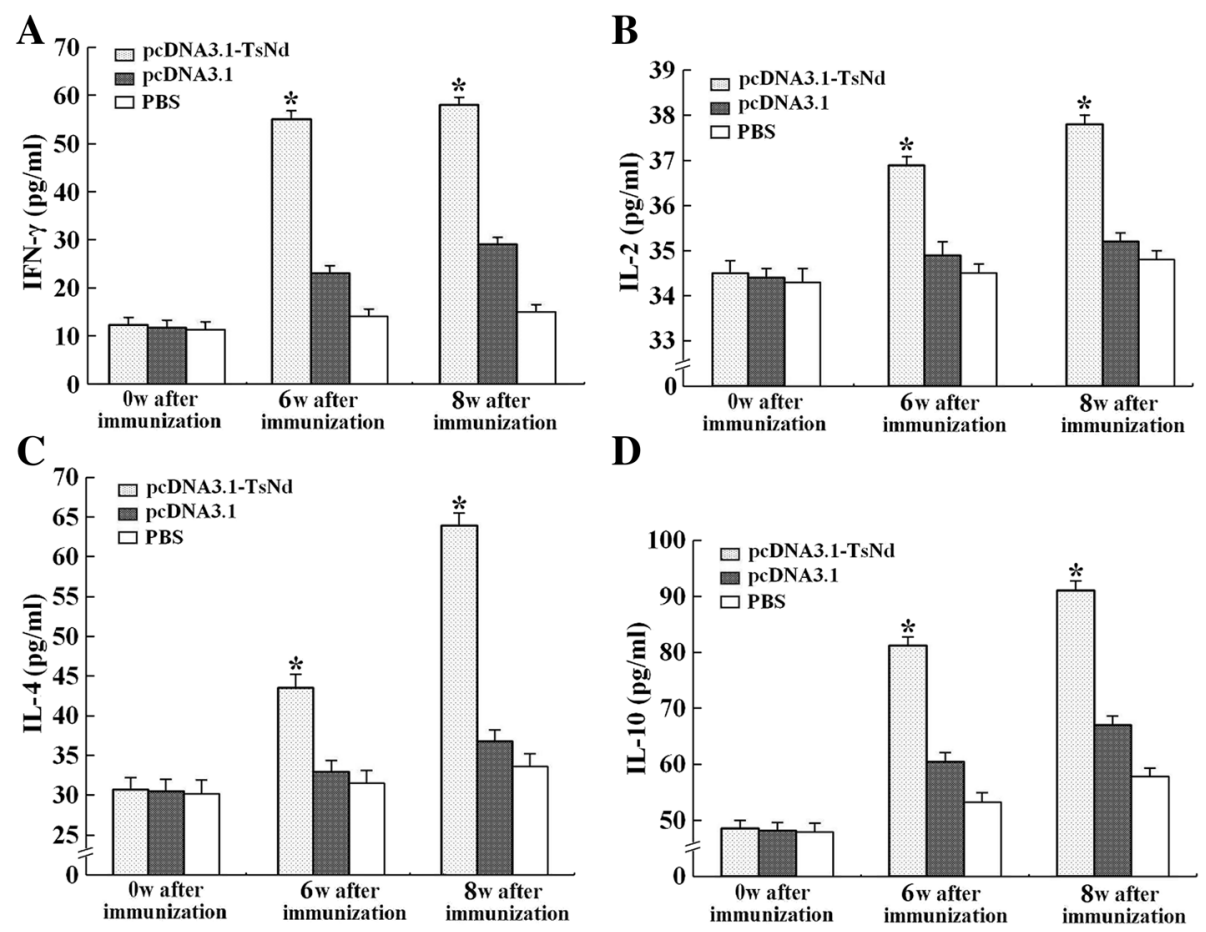

Figure 6 Splenocyte-secreted IFN- $\gamma$ (A) IL-2 (B), IL-4 (C), and IL-10 (D) upon rTsNd stimulation were detected by ELISA. Concentrations of cytokines detected in splenocyte supernatants after stimulation with the rTs Nd for $48 \mathrm{~h}$ are shown. Data are presented as the mean cytokine concentrations \pm standard deviation (SD) of 10 mice per group. ${ }^{*} P<0.05$ : indicate statistically significant differences with the empty plasmid pcDNA3.1 or PBS control group. 


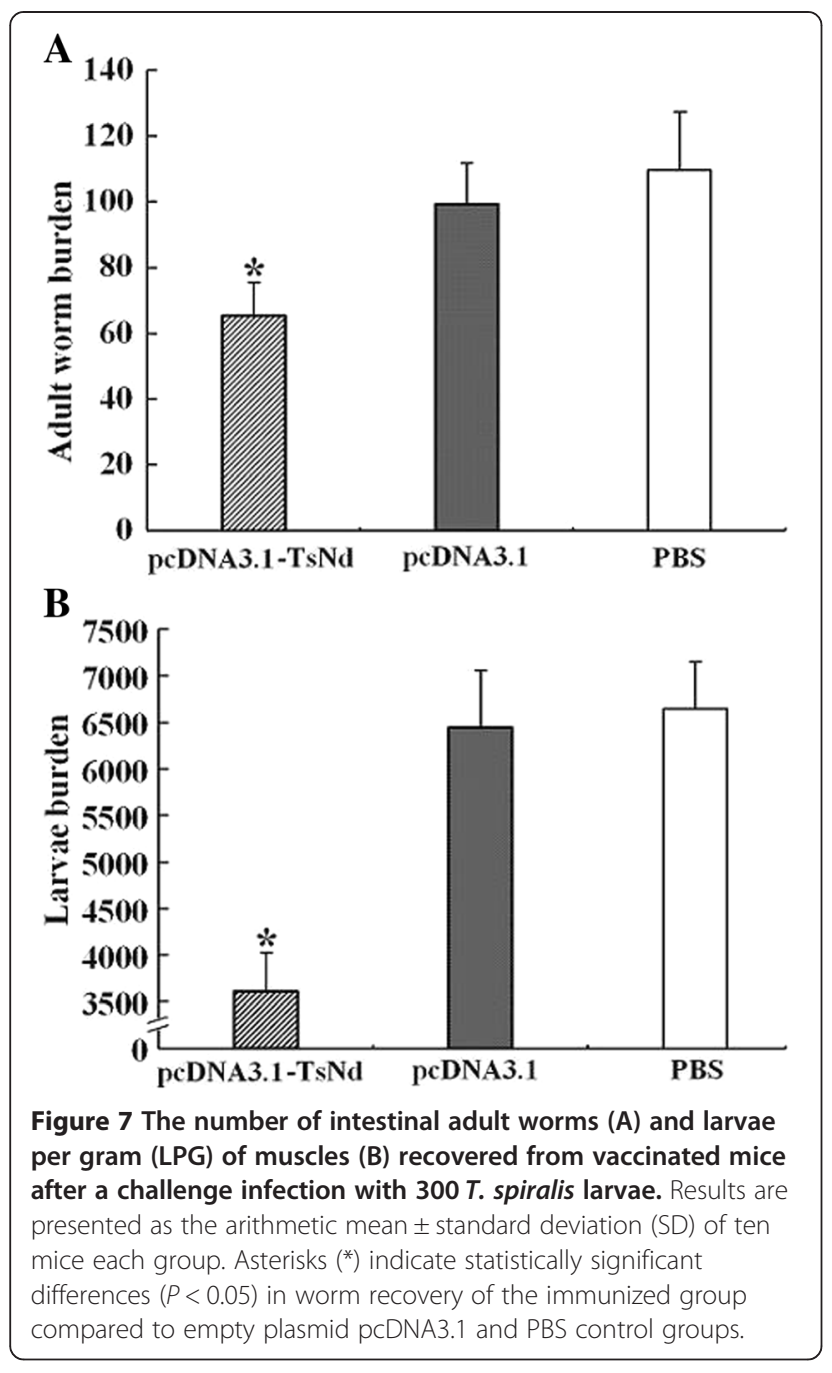

mice. The mice immunized with pcDNA3.1-TsNd displayed a $40.44 \%$ reduction in intestinal adult worms and a $53.9 \%$ reduction in muscle larval burden. The parasite burden reduction observed in this study is similar with those from the previous reports [13,15,23].

The results of RT-PCR and IFT showed that the TsNd gene was transcribed and expressed in the BHK-21 cells, suggesting that the recombinant plasmid pcDNA3.1TsNd was successfully constructed in this study. Antibody response analysis showed that intramuscular immunization with TsNd DNA induced not only the mixed systemic immune response but also the significant local mucosal IgA secretion in mice. Previous studies showed that secretory IgA ( $\operatorname{Ig} \mathrm{A})$ played a crucial role in mucosal defense and may limit penetration of pathogens through the intestinal epithelium [35]. Protective immunity against Trichinella infection is obviously associated with the production of serological IgA [36]. IgA provides intestinal protection in a non-inflammatory manner. It has been demonstrated that non-specific and specific mucosal IgA responses, as a part of the overall immune response against the parasite, act against the infective larvae and adult worms of $T$. spiralis in the mouse intestine [37]. The rapid expulsion of adult worms from the intestines might be mediated by the sIgA against surface antigens of adult worms. Passive transfer of anti-Trichinella IgA monoclonal antibodies to naive mice conferred a high level of protection (more than 95\%) against Trichinella infection [38]. The intestinal sIgA inhibited the in vitro fecundity of female worms [39]. Our results showed that vaccination with TsNd induced the production and secretion of TsNdspecific intestinal mucosal IgA. Normally, mucosal IgA production is strongly Th2-dependent; in particular, IL10 is a major cytokine that enhance IgA responses [40]. In this study, the correlation of elevated intestinal mucosal IgA level with high level of cytokines IL-10 upon TsNd immunization indicates that the cytokines may promote intestinal mucosal IgA response.

The intramuscular vaccination with pcDNA3.1-TsNd induced specific antibody (IgG, IgA) responses, suggesting the good immunogenicity of TsNd. It has been shown that different delivery systems of vaccines influence the profile of immune responses. For example, oral immunization with Ts87 DNA vaccine [37] elicited a balanced Th1/Th2 antibody response, while subcutaneous immunization with recombinant $T$. spiralis proteins induced mainly Th2 antibody responses [41,42]. In this study, the cytokines IFN- $\gamma$, IL-2, IL-4, and IL-10 secretion by the splenocytes of mice immunized with TsNd DNA significantly increased after immunization. In addition, the IgG1 levels on week 4 and 6 after immunization were more obviously higher than that of $\operatorname{IgG2a}(P<0.01)$, but it was notable that IgG2a was also induced after immunization. The results suggested that the intramuscular vaccination of mice with TsNd DNA vaccine induced a Th1/Th2-mixed type of immune response. The Th1/Th2-mixed type of immune responses had been demonstrated to be important for protective immunity against $T$. spiralis infection $[37,43]$.

Since $T$. spiralis is an antigenically complex parasite, the immune responses induced by single antigen vaccination may not be strong enough to combat the challenging infection. The vaccination of mice with $\mathrm{TsNd}$ induced a partial protective immunity against $T$. spiralis infection. Hence, the polyvalent vaccine including antigenic epitopes from $T$. spiralis different stages should be developed to improve further the efficacy of $T$. spiralis vaccine $[29,44,45]$.

\section{Conclusions}

The aim of this study was to observe the protective efficacy of intramuscular immunization with the $\mathrm{TsNd}$ DNA vaccine and its induced immune response. The 
results indicated that intramuscular immunization with TsNd DNA elicited a systemic Th1/Th2-mixed type of immune response and a strong mucosal IgA response, and produced a partial protection against $T$. spiralis infection in mice. However, the polyvalent vaccine including antigenic epitopes from $T$. spiralis different stages should be developed to improve further the efficacy of T. spiralis vaccine. Additionally, the exact mechanism of immune protection against $T$. spiralis infection needs to be investigated further.

\section{Competing interests}

The authors declare that they have no competing interests.

\section{Authors' contributions}

ZQW and JC conceived and designed the experiments. PL RDL, MW, PJ, LNL, $S R L, L G L, S B Z$, and $X Z Z$ performed some of the experiments. PL, ZQW, and $J C$ drafted and revised the manuscript. All authors read and approved the final version of the manuscript.

\section{Acknowledgements}

This work was supported by the National Natural Science Foundation of China (no. 81371843, 81271860 and 81471981).

\section{Author details}

${ }^{1}$ Department of Parasitology, Medical College, Zhengzhou University, 40 Daxue Road, Zhengzhou 450052, P. R. China. ${ }^{2}$ Department of Infection Control, The Second People's Hospital of Zhengzhou City, Zhengzhou 450000, P. R. China.

Received: 21 February 2015 Accepted: 10 March 2015

Published online: 28 March 2015

\section{References}

1. Cui J, Wang L, Sun GG, Liu LN, Zhang SB, Liu RD, et al. Characterization of a Trichinella spiralis $31 \mathrm{kDa}$ protein and its potential application for the serodiagnosis of trichinellosis. Acta Trop. 2015;142:57-63.

2. Wang L, Wang ZQ, Hu DD, Cui J. Proteomic analysis of Trichinella spiralis muscle larval excretory-secretory proteins recognized by early infection sera. Biomed Res Int. 2013;2013:139745.

3. Murrell KD, Pozio E. Worldwide occurrence and impact of human trichinellosis, 1986-2009. Emerg Infect Dis. 2011;17(12):2194-202.

4. Cui J, Wang ZQ, Xu BL. The epidemiology of human trichinellosis in China during 2004-2009. Acta Trop. 2011;118(1):1-5.

5. Cui J, Jiang P, Liu LN, Wang ZQ. Survey of Trichinella infections in domestic pigs from northern and eastern Henan, China. Vet Parasitol. 2013;194(2-4):133-5.

6. Tang B, Liu M, Wang L, Yu S, Shi H, Boireau P, et al. Characterisation of a highfrequency gene encoding a strongly antigenic cystatin-like protein from Trichinella spiralis at its early invasion stage. Parasit Vectors. 2015;8(1):78.

7. Hao Y, Zhao X, Yang J, Gu Y, Sun R, Zhu X. Monoclonal antibody targeting complement C9 binding domain of Trichinella spiralis paramyosin impairs the viability of Trichinella infective larvae in the presence of complement. Parasit Vectors. 2014;7:313.

8. Zhao X, Hao Y, Yang J, Gu Y, Zhu X. Mapping of the complement C9 binding domain on Trichinella spiralis paramyosin. Parasit Vectors. 2014;7:80.

9. Yang J, Pan W, Sun X, Zhao X, Yuan G, Sun Q, et al. Immunoproteomic profile of Trichinella spiralis adult worm proteins recognized by early infection sera. Parasit Vectors. 2015:8:20.

10. Liu RD, Wang ZQ, Wang L, Long SR, Ren HJ, Cui J. Analysis of differentially expressed genes of Trichinella spiralis larvae activated by bile and cultured with intestinal epithelial cells using real-time PCR. Parasitol Res. 2013;112(12):4113-20.

11. Ren HJ, Liu RD, Wang ZQ, Cui J. Construction and use of a Trichinella spiralis phage display library to identify the interactions between parasite and host enterocytes. Parasitol Res. 2013;112(5):1857-63.

12. Ren HJ, Cui J, Yang W, Liu RD, Wang ZQ. Identification of differentially expressed genes of Trichinella spiralis larvae after exposure to host intestine milieu. PLoS One. 2013;8(6):e67570.
13. Long S, Wang Z, Liu R, Liu L, Li L, Jiang P, et al. Molecular identification of Trichinella spiralis nudix hydrolase and its induced protective immunity against trichinellosis in BALB/c mice. Parasit Vectors. 2014;7(1):600.

14. Min J, Qu D, Li C, Song X, Zhao Q, Li XA, et al. Enhancement of protective immune responses induced by Toxoplasma gondii dense granule antigen 7 (GRA7) against toxoplasmosis in mice using a prime-boost vaccination strategy. Vaccine. 2012;30(38):5631-6.

15. Wang ZQ, Cui J, Wei HY, Han HM, Zhang HW, Li YL. Vaccination of mice with DNA vaccine induces the immune response and partial protection against $T$. spiralis infection. Vaccine. 2006;24(8):1205-12.

16. Tang F, Xu L, Yan R, Song X, Li X. Evaluation of the immune response induced by DNA vaccines expressing MIF and MCD-1 genes of Trichinella spiralis in BALB/c mice. J Helminthol. 2012;86(4):430-9.

17. Li F, Cui J, Wang ZQ, Jiang P. Sensitivity and optimization of artificial digestion in the inspection of meat for Trichinella spiralis. Foodborne Pathog Dis. 2010;7(8):879-85.

18. Despommier D. A circular thermal migration device for the rapid collection of large numbers of intestinal helminths. J Parasitol. 1973;59(5):933-5.

19. Takada N, Tada T. Collection of newborn larvae of Trichinella spiralis in vitro. Jpn J Parasitol. 1988;7(1-2):251-3.

20. Kozak M. An analysis of 5'-noncoding sequences from 699 vertebrate messenger RNAs. Nucleic Acids Res. 1987;15(20):8125-48.

21. Yang W, Li L, Liu R, Sun G, Liu C, Zhang S, et al. Molecular identification and characterization of Trichinella spiralis proteasome subunit beta type-7. Parasit Vectors. 2015;8(1):18.

22. Santos JJ, Cordeiro MT, Bertani GR, Marques ET, Gil LH. A two-plasmid strategy for engineering a dengue virus type 3 infectious clone from primary Brazilian isolate. An Acad Bras Cienc. 2014;86(4):1749-59.

23. Cui J, Ren HJ, Liu RD, Wang L, Zhang ZF, Wang ZQ. Phage-displayed specific polypeptide antigens induce significant protective immunity against Trichinella spiralis infection in BALB/c mice. Vaccine. 2013;31(8):1171-7.

24. Cui J, Liu RD, Wang L, Zhang X, Jiang P, Liu MY, et al. Proteomic analysis of surface proteins of Trichinella spiralis muscle larvae by two-dimensional gel electrophoresis and mass spectrometry. Parasit Vectors. 2013;6:355.

25. Wang L, Cui J, Hu DD, Liu RD, Wang ZQ. Identification of early diagnostic antigens from major excretory-secretory proteins of Trichinella spiralis muscle larvae using immunoproteomics. Parasit Vectors. 2014;7:40.

26. Zhang $Y$, Wang $Z$, Li L, Cui J. Molecular characterization of Trichinella spiralis aminopeptidase and its potential as a novel vaccine candidate antigen against trichinellosis in BALB/C mice. Parasit Vectors. 2013;6:246.

27. Pompa-Mera EN, Yepez-Mulia L, Ocana-Mondragon A, Garcia-Zepeda EA, Ortega-Pierres G, Gonzalez-Bonilla CR. Trichinella spiralis: intranasal immunization with attenuated Salmonella enterica carrying a gp43 antigenderived 30mer epitope elicits protection in BALB/C mice. Exp Parasitol. 2011;129(4):393-401.

28. Dea-Ayuela MA, Rama-Iniguez S, Bolas-Fernandez F. Vaccination of mice against intestinal Trichinella spiralis infections by oral administration of antigens microencapsulated in methacrilic acid copolymers. Vaccine. 2006;24(15):2772-80.

29. Gu Y, Wei J, Yang J, Huang J, Yang X, Zhu X. Protective immunity against Trichinella spiralis infection induced by a multi-epitope vaccine in a murine model. PLoS One. 2013:8(10):e77238.

30. Cui J, Wang ZQ. An epidemiological overview of swine trichinellosis in China. Vet J. 2011;190(3):323-8.

31. Vu Thi N, Trung DD, Litzroth A, Praet N, Nguyen Thu H, Nguyen Manh H, et al. The hidden burden of trichinellosis in Vietnam: a postoutbreak epidemiological study. Biomed Res Int. 2013;2013:149890.

32. Liu XD, Wang XL, Bai X, Liu XL, Wu XP, Zhao Y, et al. Oral administration with attenuated Salmonella encoding a Trichinella cystatin-like protein elicited host immunity. Exp Parasitol. 2014;141:1-11.

33. Li L, Saade F, Petrovsky N. The future of human DNA vaccines. J Biotechnol. 2012;162(2-3):171-82.

34. Song $X$, Xu L, Yan R, Huang $X$, Shah MA, Li X. The optimal immunization procedure of DNA vaccine PCDNA-TA4-IL-2 of Eimeria tenella and its crossimmunity to Eimeria necatrix and Eimeria acervulina. Vet Parasitol. 2009;159(1):30-6.

35. Macpherson AJ, Slack E. The functional interactions of commensal bacteria with intestinal secretory IgA. Curr Opin Gastroenterol. 2007;23(6):673-8.

36. Martinez-Gomez F, Santiago-Rosales R, Ramon Bautista-Garfias C. Effect of Lactobacillus casei Shirota strain intraperitoneal administration in CD1 mice on the establishment of Trichinella spiralis adult worms and on IgA anti-T. spiralis production. Vet Parasitol. 2009;162(1-2):171-5. 
37. Yang Y, Zhang Z, Yang J, Chen X, Cui S, Zhu X. Oral vaccination with Ts87 DNA vaccine delivered by attenuated Salmonella typhimurium elicits a protective immune response against Trichinella spiralis larval challenge. Vaccine. 2010;28(15):2735-42.

38. Inaba T, Sato H, Kamiya H. Monoclonal IgA antibody-mediated expulsion of Trichinella from the intestine of mice. Parasitology. 2003;126(Pt 6):591-8.

39. Robinson K, Bellaby T, Wakelin D. Oral and parenteral vaccination against Trichinella spiralis infections in high- and low-responder mice. Int J Parasitol. 1995;25(8):989-92.

40. Yamamoto M, Vancott JL, Okahashi N, Marinaro M, Kiyono H, Fujihashi K, et al. The role of Th1 and Th2 cells for mucosal IgA responses. Ann N Y Acad Sci. 1996;778:64-71.

41. Wang S, Zhu X, Yang Y, Yang J, Gu Y, Wei J, et al. Molecular cloning and characterization of heat shock protein 70 from Trichinella spiralis. Acta Trop. 2009;110(1):46-51.

42. Wei J, Gu Y, Yang J, Yang Y, Wang S, Cui S, et al. Identification and characterization of protective epitope of Trichinella spiralis paramyosin. Vaccine. 2011;29(17):3162-8.

43. Deville S, Pooter A, Aucouturier J, Laine-Prade V, Cote M, Boireau P, et al. Influence of adjuvant formulation on the induced protection of mice immunized with total soluble antigen of Trichinella spiralis. Vet Parasitol. 2005;132(1-2):75-80

44. Yang $Y$, Yang $X$, Gu $Y$, Wang $Y$, Zhao $X$, Zhu $X$. Protective immune response induced by co-immunization with the Trichinella spiralis recombinant Ts87 protein and a Ts87 DNA vaccine. Vet Parasitol. 2013;194(2-4):207-10.

45. Pompa-Mera EN, Arroyo-Matus P, Ocana-Mondragon A, Gonzalez-Bonilla CR, Yepez-Mulia L. Protective immunity against enteral stages of Trichinella spiralis elicited in mice by live attenuated Salmonella vaccine that secretes a 30-mer parasite epitope fused to the molecular adjuvant C3d-P28. Res Vet Sci. 2014;97(3):533-45.

\section{Submit your next manuscript to BioMed Central and take full advantage of:}

- Convenient online submission

- Thorough peer review

- No space constraints or color figure charges

- Immediate publication on acceptance

- Inclusion in PubMed, CAS, Scopus and Google Scholar

- Research which is freely available for redistribution 